\title{
Kebijakan Politik Luar Negeri Indonesia Masa Kabinet Djuanda 1957-1959
}

\author{
FEBTA PRATAMA AMAN \\ Universitas Negeri Yogyakarta \\ e-mail : ayodhyaafebta@yahoo.com
}

\begin{abstract}
Abstrak
Penelitian ini bertujuan (1) mendeskripsikan terbentuknya sekilas kehidupan, susunan dan program kerja kabinet, (2) menganalisis kebijakan politik luar negeri Indonesia beserta pelaksanaannya, (3) menganalisis keberhasilan dan dampak yang ditimbulkan dari kebijakan, dan (4) mengetahui dan mendeskripsikan proses berakhirnya kabinet. Menggunakan metode penelitian sejarah kritis dengan menentukan topik penelitian, heuristik atau pengumpulan sumber penelitian, verifikasi atau kritik sumber, interpretasi dan historiografi. Hasil penelitian (1) Kabinet Karya menggantikan kabinet Ali II yang mengundurkan diri, kabinet ini disebut zaken kabinet, program kabinet ini disebut pancakarya, (2) kebijakan politik luar negeri terlihat dari program dekolonisasi hokum, (3) Tingkat keberhasilan kabinet Djuanda belum berhasil dengan maksimal. Kebijakan politik ini membawa dampak bagi kehidupan baik itu dari aspek politik, ekonomi, kewilayahan, pertahanan keamanan, dan sosial budaya. (4) Kabinet Djuanda demisioner karena kegagalan Konstituante menyusun Undang-Undang Dasar Baru dan keluarnya Dekrit Presiden Soekarno tanggal 5 Juli 1959.
\end{abstract}

Kata kunci: Kebijakan Politik Luar Negeri, Kabinet Djuanda, Deklarasi Djuanda, Tahun 1957-1959.

\begin{abstract}
This research aims to (1) describe the formation of the cabinet's life, structures and programs, (2) analyze the Indonesian foreign policy and its implementation, (3) analyze the success and impact of the policies, and (4) identify and describe the process of cabinet ending. This research employs critical historical research methods to determine the topic of research, heuristic or collection of research sources, verification or sources criticism, interpretation and historiography. The research findings are (1) Kabinet Karya replaces Ali II cabinet which had resigned, this cabinet is called zaken cabinet, the cabinet's program is called Pancakarya, (2) The foreign policy can be seen from the legal decolonization, (3) The Djuanda's cabinet did not gain its success optimally. This political policy has had implications for the good life for some sectors such as political, economic, territorial, defense and security, and socio-cultural, (4) The Djuanda's Cabinet became outgoing because of the Constituent failure in composing new Constitution and the issuance of President Sukarno Decree dated July 5, 1959.
\end{abstract}

Keywords: policy foreign policy, Djuanda cabinet, Djuanda declaration, year 1957-1959. 


\section{PENDAHULUAN}

Tahun 1950-1959 ialah masa dimana Indonesia menjalankan sistem demokrasi liberal dengan pemerintahan parlementer. Tercatat ada tujuh kabinet yang menjalankan roda pemerintahan. Kabinet tersebut adalah kabinet Natsir pada September 1950-Maret 1951, Kabinet Sukiman pada April 1951-Februari 1952, Kabinet Wilopo pada April 1952-1953, Kabinet Ali Sastroamidjojo I pada Juli 1953-1955, Kabinet Burhanudin Harahap pada 1955-1956, Kabinet Ali Sastroamidjojo II pada Maret 1955-1957, dan Kabinet Djuanda 1957-1959 (Zulkarnain, 2012). Kabinet Djuanda atau kabinet Karya ini ialah kabinet ketujuh atau kabinet terakhir pada masa demokrasi parlementer. Kabinet ini terbentuk karena kabinet sebelumnya yakni kabinet Ali II sudah demisioner. Diawal kerjanya mempunyai dan menentukan lima program kerja yang disebut dengan program pancakarya. Program pancakarya ini meliputi Membentuk Dewan Nasional, Normalisasi Keadaan Republik Indonesia, Melanjutkan Pembatalan KMB, Memperjuangkan Irian Barat, serta Mempercepat Pembangunan.

Program kerja tersebut kemudian diuraikan menjadi beberapa kebijakan. Salah satu kebijakan tersebut ialah kebijakan politik di sektor maritim yakni Deklarasi Djuanda. Deklrasi Djuanda ini di keluarkan tepat tanggal 13 Desember 1957 yakni sebuah kebijakan yang mengatur batas wilayah Laut Indonesia. Hal ini di lakukan untuk mempertahankan negara Indonesia sebagai negara kesatuan dan juga untuk merubah batas laut territorial Indonesia (A. Hamzah, 1984).

Secara histories batas wilayah laut Indonesia telah dibuat oleh pemerintah Kolonial Belanda, yaitu dalam Territorial Zee Maritieme Kringen Ordonantie tahun 1939, yang menyatakan bahwa lebar wilayah laut Indonesia adalah tiga mil diukur dari garis rendah di pantai masing-masing pulau Indonesia. Karenanya di antara ribuan pulau di Indonesia terdapat laut-laut bebas yang membaha yakan kepentingan bangsa Indonesia sebagai Negara kesatuan.

Deklarasi Djuanda ini bertujuan untuk menjawab masalah batas laut Indonesia. Kebijakan politik luar negeri Pemerintah Indo- nesia dibahas dalam deklarasi ini. Deklarasi Djuanda ini selalu di bawah dalam forum internasional, misalnya dalam UNCLOS (United Nations Conference On The Law Of The Sea). Untuk memperkuat posisi Deklarasi ini, maka pemerintah menaikkan statusnya menjadi Undang-undang tentang Perairan. Tujuan di keluarkannya Deklarasi Djuanda ini ialah membatasi kapan asing keluar masuk dalam wilayah Indonesia, serta untuk menyatukan wilayah yang terpencar dalam gugusan pulau. Dengan adanya Deklarasi Djuanda ini, kekayaan alam Indonesia dapat di jaga dari tangan asing, dan di manfaatkan oleh masyarakat Indonesia sendiri. Deklarasi Djuanda membawa dampak luar biasa bagi negara Indonesia, itu terlihat dari aspek Wilayah, Batas laut territorial selebar $12 \mathrm{mil}$, Batas zona bersebelahan adalah 24 mil, Batas ZEE adalah 200 mil, Batas landas benua lebih dari 200 mil. Aspek wilayah, Indonesia menjadi tambah luas wilyahnya, hampir bertambah setengah dari Wilayah Negara RI yang semula luasnya 2. $027.087 \mathrm{~km} 2$ (daratan) bertambah luas lebih kurang menjadi 5. 193. $250 \mathrm{~km} 2$ (terdiri atas daratan dan lautan). Ini berarti bertambah kira-kira 3. 106. $163 \mathrm{~km} 2$ atau kita-kira 145\% (Dewan Kelautan Indonesia, 2009).

Tujuan yang ingin di capai dari penelitian ini adalah memberikan gambaran tentang proses terbentuknya kabinet Djuanda atau kabinet karya. mengkaji dan menganalis tentang kebijakan politik Luar negeri kabinet karya serta pelaksanaannya. menganalis tingkat keberhasilan dan dampak yang muncul dari kebijakan tersebut. memberikan gambaran umum tentang proses berakhirnya kabinet Djuanda.

\section{METODE}

Penelitian ini menggunakan metode penelitian sejarah yang sesuai, yakni a). pemilihan topik, b). Heuristik (pengumpulan sumber), c). Verifikasi (Kritik sumber), d). Interpretasi, e). Historiografi (Kuntowijoyo, 1994). Penyajian terakhir dari penelitian ini ialah sebuah tulisan sejarah mengenai Kebijakan politik luar negeri Indonesia masa kabinet Djuanda tahun 1957-1959.. 


\section{HASIL DAN PEMBAHASAN}

\section{Terbentuknya Kabinet Djuanda}

\section{Sekilas tentang kehidupan Ir. Djuanda}

Tasikmalaya sebuah kota kecil di bumi Parahyangan, bumi dimana para dewa bersemayam. Tanggal 14 Januari 1911 Raden Kartawijaya dan Nyi Momot sangat bahagia karena putera sulung mereka lahir pada tanggal tersebut. Putera itu diberi nama Djuanda. Raden Kartawijaya merupakan guru di sekolah Belanda, sedangkan ibunya Nyi Momot berkerja sebagai ibu rumah tangga (Mirnawati, 2012). Dalam asuhan sang ayah bunda pun, ia tumbuh besar menjadi seorang yang biasa saja. Memasuki usia untuk sekolah, oleh sang ayah Djuanda kecil di masukkan ke HIS. Sejak sekolah di HIS sifat dan watak Djuanda mulai kelihatan yakni watak pendiam. Tetapi, dalam hal pelajaran Djuanda Memiliki Kemajuan yang pesat. Kemajuan ini terlihat dari mata pelajaran berhitung dan bahasa belanda.

Djuanda kemudian melanjutkan pendidikannya ke ELS ( Europese Lagere School) yakni sebuah sekolah yang di peruntukkah bagi anak-anak orang belanda dan keturunan belanda. Anak bumi Putera bisa sekolah tetapi dengan pengecualian. Tahun 1924 Djuanda menamatkan ELS dan menempuh ujian untuk masuk HBS (Hogore Burger School). Setelah menyelesaikan studinya di HBS, Djuanda mendapatkan beasiswa untuk melanjutkan pendidikannya ke perguruan tinggi. Djuanda mendapatkan beasiswa dari pemerintah belajar THS ( Techische Hogeschool ) Bandung. THS ini kelak menjadi Institute Teknologi Bandung atau ITB sekarang. Selama kuliah di THS inilah mulai tumbuh benih benih dunia pergerakan dan cinta tanah air dalam diri Djuanda. terutama saat mengikuti kegiatan perkumpulan diskusi mahasiswa ISV yang didirikan oleh tokoh pergerakan favoritnya yakni Soekarno. Lambat laun ia pun duduk sebagai Ketua ISV. Tidak Hanya ISV yang membawa Djuanda memasuki dunia Perge rakan, Djuanda juga bergabung dalam Orga nisasi kedaerahan sunda yang di sebut de ngan Paguyuban Pasundan. Djuanda di Organisasi ini menempati posisi sebagai Sekretaris. Jabatan ini di embannya selama lebih kurang lima tahun. ISV dan Paguyuban Pasundan telah membawa Djuanda untuk ikut andil membangun bangsa dan negara.

Tanggal 17 Agustus 1945 merupakan hari bersejarah bagi bangsa Indonesia karena bangsa Indonesia resmi merdeka dan menjadi sebuah negara. Proklamasi kemerdekaan ini membuat rakyat dengan riuh riah menyambut dan menyebarkannya keseluruh wilayah Indonesia. Pemerintahan Indonesia mulai berjalan dengan Ir. Sukarno dan Moh. Hatta Sebagai Wakil Presiden. Dalam era yang disebut dengan masa revolusi fisik ini, Djuanda sudah mulai terlibat dalam peme rintahan yakni Sebagai kepala Djawatan Kereta Api Republik Indonesia. Pengangkatan Djuanda sebagai kepala DKA RI sesuai dengan Maklumat Kementrian Perhubungan no. 1/KA tanggal 23 Januari 1946. Sejak saat itu Djuanda sudah menceburkan diri dalam dunia politik, yakni dengan masuknya nama beliau menjadi salah satu menteri. Djuanda ialah menteri marathon, maksudnya ialah Djuanda selalu menjadi menteri pada saat pergantian kabinet. Djuanda pernah menjadi Menteri Negara, Menteri Perhubungan, Menteri Kemakmuran, dan puncak karier beliau ialah saat menjadi perdana menteri di era sistem parlementer. dalam kabinet Syahrir, Moh. Hatta, Ali Sastroamijoyo Djuanda selalu duduk dalam posisi menteri (L. O. Nanulaita, 1983).

Tahun 1957-1959 merupakan puncak karier politiknya. Dimana selama jangka waktu tahun tersebut Djuanda di tunjuk untuk memimpin sebuah kabinet. Itu artinya Djuanda menempati posisi tertinggi dalam strata politik parlementer yakni sebagai kepala pemerintahan atau Perdana Menteri. Selama menjadi Perdana Menteri, kabinet yang dipimpinnya ialah kabinet yang diisi oleh orang-orang professional. Sehingga kabinet yang Djuanda pimpin dikenal dengan Zaken Kabinet atau Kabinet Ahli. Selama menjalan kan pemerintahan, banyak kebijakan yang dikeluarkan salah satunya ialah kebijakan politik luar negeri yakni Deklarasi Djuanda. 
Deklarasi Djuanda merupakan salah satu gebrakan kabinet yang di pimpinnya. Deklarasi Djuanda menjadi politik luar negeri bidang kemaritiman. Dimana dengan Deklrasi tersebut, Indonesia resmi menjadi sebuah negara kepulauan. Walaupun banyak mendapat tantangan, tetapi Deklarasi ini menjadi tonggak keutuhan dan kesatuan bangsa negara dan Indonesia. Tahun 1963 Ir. Djuanda dipanggil menghadap kembali kepada sang Pencipta. Atas jasa dan perjuangan beliau, negera melalui pemerintah memberikan gelar pahlawan nasional kepada Ir. Djuanda. Selain itu nama Ir. Djuanda diabadikan menjadi nama berbgai tempat, seperti nama jalan Djuanda, nama stasiun di Jakarta yakni stasiun Djuanda, dan nama sebuah Bandar Udara internasional di Surabaya yakni Bandara Djuanda Surabaya (Mirnawati, 2012).

\section{Proses Terbentuknya Kabinet Djuanda}

Tanggal 20 Maret 1956 Ali Sastroamijoyo dilantik oleh Presiden Soekarno sebagai Perdana Menteri. Ali Sastroamijoyo untuk kedua kalinya di tunjuk menjadi formatur kabinet. Kabinet ini hanya berlangsung selama satu tahun saja. Karena berbagai tekanan dan peristiwa yang mengiringi perjalanan kabinet ini. Selama satu tahun masa kabinet ini, telah terjadi a) Parlemen pemilihan umum telah berputar, b) Konstituante baru saja melangkah, c) Rencana Pembangunan Lima Tahun Sudah di Setujui tetapi berjalan seret, d) Pimpinan Pusat TNI berhasil distabilkan (angkatan darat), e) Gerakan daerah Mengancam kesatuan dan persatuan bangsa dan negara, f) Hatta mengundurkan diri dari pemerintahan, g) Munculnya Konsepsi Pre siden, h) Pemberontakan daerah berlangsung terus.

Gerakan daerah ini muncul sebagai bentuk dan protes terhadap pemerintahan pusat. Gerakan ini muncul karena rasa tidak puas daerah terhadap kebijakan pemerintahan pusat. Gerakan daerah ini memunculkan dewan-dewan daerah yang dipimpin oleh perwira daerah. Merebut pemerintahan sipil dan dikuasai oleh militer. Pembentukan dewan daerah ini terjadi di Sumatera dan Sulawesi.

Pada tahun 1956 ini Wakil Presiden Moh.
Hatta menyatakan mengundurkan diri seba gai Wakil Presiden. Pengunduran diri Moh. Hatta tersebut ditolak oleh pimpinan TNI yang ada diluar Jawa. Pengunduran hatta ini menyebabkan hilangnya kepercayaan masyarakat terhadap pemerintah pusat. $\mathrm{Pe}$ ngunduran Hatta ini menandai berakhirnya masa Dwitunggal. Pengunduran ini berakibat ke partai politik yakni, PSI dan Masyumi mendukung Moh. Hatta sedangkan PNI dan PKI dibawah garis Soekarno.

Pada tahun ini juga muncul sebuah gagasan dari Presiden, gagasan tersebut lebih dikenal dengan konsepsi Presiden. Tepatnya tanggal 21 Februari 1957 Presiden Soekarno mengumumkan Konsepsinya tersebut. Konsepsi Presiden ini malah membuat negara tambah ruwet dan memunculkan masalah baru. Masalah tersebut ialah penentangan dari berbagai tokoh politik saat itu. Konsepsi Presiden yang diumumkan tersebut berisi, a) Sistem demokrasi parlementer di ganti de ngan sistem demokrasi terpimpin, b) di bentuk suatu kabinet gotong royong yang anggotanya memasukkan partai-partai dalam parlemen. Dalam hal ini kabinet kaki empat, c) pembentukan Dewan Nasional, yang beranggotakan golongan fungsional, buruh, tani, pengusaha, dan golongan perwira Militer, dimasukkan juga dalam Dewan Nasional, Seperti Kepala Staf AD, AL, AU, Kapolri, Jaksa Agung (Kementrian Penerangan RI, 1970). Pada tahun ini juga banyak muncul perlawanan daerah yang bersifat Separatis bahkan bisa dikatakan makar terhadap sebuah negara. Sementara itu dikalangan internal kabinet sendiri banyak yang bermasalah, Sehingga berujung pada ditariknya menteri-menteri oleh partai politik tertentu. Masalah yang semakin memuncak ini membuat Ali Sastroamijoyo akhirnya mengembalikan mandatnya kepada Presiden Soekarno.

Pada tanggal 14 Maret 1957, Perdana Menteri Ali Sastroamijoyo menyerahkan mandat kepada Presiden Soekarno. Kabinet ini Bubar bukan karena mosi tidak percaya oleh parlement tetapi karena dalam tubuh kabinet terdapat perpecahan, sehingga partai banyak yang menarik menterinya dari kabi- 
net. Salah satunya ialah ditariknya beberapa menteri dari partai Masyumi (Ali Sastroamijoyo, 1974). Setelah penyerahan mandat dari Perdana Menteri Ali Sastroamijoyo, Presiden Sukarno mengatakan seluruh negara Indonesia dalam keadaan bahaya atau disebut SOB (N. H. T Siahaan dkk, 1989). SOB ini di tanda tangani oleh perdana menteri dan Menhan Ali Sastroamijoyo yang sudah Demisioner.

Segera setelah itu, pada tanggal 15 Maret 1957 Presiden Soekarno menunjuk Soewiryo sebagai formatur untuk membentuk dan menyusun kabinet baru. Usaha Pertama ini gagal, tanggal 25 Maret 1957 Presiden memberi tugas baru kepada Soerwiryo, tugas tersebut ialah membentuk suatu Zaken Kabinet. Soewiryo, untuk kedua kalinya gagal dalam membentuk dan menyusun kabinet yang diinginkan oleh Presiden. Hingga akhirnya Presiden Sukarno menunjuk Presiden sen diri (warga negara) sebagai formatur kabinet. Soekarno kemudian mengundang beberapa orang tokoh untuk mengadakan rapat tertutup, rapat tertutup tersebut membahas seputar masalah kabinet, dan juga meminta saran untuk kabinet yang baru ini. Presiden juga memberikan blangko yag isinya saran terhadap kabinet baru dan juga kesediaan diri jika nanti dipilih oleh Presiden untuk duduk di kabinet. Sebagian besar setuju dan menyatakan bersedia jika nanti duduk di dalam cabinet (Duta Masyarakat, 1957).

Soekarno kemudian mengundang Perdana Menteri Demisioer Ali Sastroamijoyo untuk dimintai saran dan usul siapa yang tepat untuk memimpin kabinet ini. Soekarno mengatakan bahwa kabinet initidak didirikan atas dasar kepentingan partai, oleh karena itu yang cocok untuk memimpin kabinet ini ialah orang yang berasal dari golongan non partai. Ali Sastroamijoyo langsung mengatakan "Ir. Djuanda", Ali mengatakan bahwa Ir. Djuanda ialah negarawan yang tidak berasal dari partai politik manapun. Ir. Djuanda ialah seorang teknokrat, tetapi cakap dan berhasil dalam memimpin. Hal ini dijelaskan Ali kepada Soekarno karena Ali telah bekerja sama selama Ali masih jadi Perdana Menteri.

Setelah meminta dan mendengarkan beberapa pertimbangan dan masukan dari tokoh-tokoh politik. Akhirnya Formatur Soe karno mengumumkan kabinet bentukannya pada tanggal 8 April 1957 di Istana Bogor. Formatur Sukarno membentuk Kabinet Darurat Ekstraparlementer dengan Ir. Djuanda se bagai Perdana Menteri. Pertimbangan formatur Soekarno menunjuk Ir. Djuanda sebagai Perdana Menteri ialah karena kecakapannya dalam memimpin dan ketenangannya dalam memimpin dan bukan dari kalangan partai politik. Saat diajukan sebagai Perdana Menteri, banyak orang yang setuju dan menaruh respek kepada Djuanda. Bahkan Presiden Sukarno tidak segan memberikan jabatan se bagai Menteri Pertahanan kepada Ir. Djuanda. Itu artinya Ir. Djuanda merangkap jabatan, yakni selain Perdana Menteri juga sebagai Menteri Pertahanan.

Kabinet Darurat Ekstraparlementer dibawah pimpinan Perdana Menteri Djuanda, diberi nama Zaken Kabinet atau Kabinet Karya. Disebut Zaken Kabinet atau Kabinet Karya,karena dalam kabinet ini, tidak ada unsur partai politik, kabinet ini dalam pendiriannya tidak diusung oleh partai politik. Kabinet ini di isi oleh kaum profesional sesuai dengan bidangnya. Walaupun ada beberapa orang menterinya berasal dari partai politik, tetapi mereka tidak berada dalam partai politik dan tidak aktif dalam pergerakan partai politik. Serta dalam kabinet ini, terdapat dua orang menteri yang berasal dari angkatan bersenjata.

Kabinet Djuanda resmi dilantik oleh Pre siden Sukarno Tanggal 9 April 1957 berdasarkan surat Keputusan Presiden R. I No 108 tahun 1957 di Istana Negara (P. N. H. Simanjutak, 2003). Dilantiknya Ir. Djuanda menjadi Perdana Menteri menandai berakhirnya status Ali Sastroamijoyo sebagai Perdana Menteri Demisioner. Kabinet karya adalah Kabinet terakhir dalam sistem parlementer dan era demokrasi Liberal. Kabinet Karya ialah kabinet yang paling lama usianya jika dibandingkan dengan kabinet lain di era sebelumnya, dan juga di era Demokrasi Liberal. Kabinet Karya menjalankan pemerintahan kurang lebih selama dua tahun. Dengan keluarnya surat 
Keputusan Presiden RI ini maka resmilah Ir. Djuanda menjadi Perdana Menteri.

\section{Susunan dan Program Kerja Kabinet Djuanda}

Pasca penyerahan mandat dari Perdana Menteri Ali II, Sukarno membentuk Kabinet baru, yang dinamakan Kabinet Karya. Kabinet Karya ini di bentuk berdasarkan surat Keputusan Presiden No. 108 1957. Tanggal 9 April 1957 Presiden Sukarno mengumumkan kabinet hasil bentukannya, kabinet tersebut terdiri dari satu orang Perdana Menteri, dua Wakil Perdana Menteri dan dua puluh Kementerian. Kabinet Djuandapun tidak luput dari tambal sulam kabinet. Setelah beberapa kali melakukan Reshuffle, maka susunan terakhir kabinet Djuanda tahun 1959 adalah terdiri dari satu orang perdana menteri, 3 orang wakil Perdana Menteri, dan 26 kementerian (Bibit Suprapto, 1985).

Segera setelah susunan kabinet terbentuk dan sudah dilantik, langkah berikutnya yang diambil oleh Perdana Menteri Djuanda adalah menentukan program kerja. Kabinet Karya atau Zakent kabinet ini mempunyai Program kerja yang sederhana saja. Kabinet ini Punya lima Program dalam kerjanya, lima program kerja tersebut di sebut dengan pancakarya. Adapun kelima program kerja tersebut ialah.

- Membentuk Dewan Nasional

- Normalisasi Keadaan Republik Indonesia

- Melanjutkan Pembatalan KMB

- Perjuangan Irian Barat

- Mempergiat Pembangunan.

\section{Kebijakan Politik Luar Negeri dan Pelak- sanaannya}

Setelah dilantik tanggal 9 April 1957, Ir. Djuanda resmi memegang jabatan sebagai Perdana Menteri. Dalam sidang pertama Kabinet, Perdana Menteri Djuanda me ngatakan bahwa kabinetnya ialah kabinet darurat ekstra parlementer. kabinet ini tidak diisi oleh kaum politik, atau pun di dukung oleh partai politik. Kabinet ini ialah kabinet non partai politik. Sesuai dengan tujuan semula, bahwa kabinet ini ialah kabinet hasil bentukan Presiden, dimana pada saat itu presiden menginginkan kabinet yang sesuai dengan tujuannya, yakni sesuai dengan konsepsi presiden. Maka program kerja kabinet ini tidak jauh dari apa yang diinginkan oleh Presiden Soekarno. Program kerja kabinet ini sering disebut dengan Pancakarya. Lima program kerja tersebut kemudian diterjemahkan dalam beberapa kebijakan strategis, baik kebijakan politik maupun kebijakan dibidang lainnya. salah satu kebijakan kabinet ini ialah kebijakan politik luar negeri. Kebijakan politik ini lebih fokus kebijakan politik bidang hukum kemaritiman.

Kebijakan politik luar negeri kabinet ini antara lain terlihat di sektor maritim. Kebijakan tersebut ialah dengan melakukan dekolonisasi bidang kemaritiman, yakni Deklarasi Djuanda tanggal 13 Desember 1957. Deklarasi ini menghapus dan tidak memberlakukan kembali peraturan yang dibuat oleh pemerintah Hindia Belanda. Deklarasi ini tidak hanya berimplikasi secara nasional tetapi juga internasional. Deklarasi Djuanda ini merupakan sebuah Kebijakan politik luar negeri Indonesia, karena PrinsipPrinsip dalam Deklarasi ini selalu di bawah ke forum internasional $\mathrm{PBB}$, salah satunya di bawah dan dibicarakan dalam Forum PBB bidang kelautan dan hukum Laut, UNCLOS (Singgih Tri Sulistiyono, 2009).

Wilayah maritim Indonesia sangatlah luas, dan sebelum belanda masuk atau bangsa barat masuk ke bumi Nusantara, belum ada pembatasan-pembatasan mengenal wilayah laut. Laut adalah milik bersama sehingga penguasaannya juga bersama-sama. Masalah dan soal batas wilayah laut ini mulai muncul saat bangsa barat mulai menanamkan keku asaannya di Nusantara. Batas wilayah laut atau maritim ini muncul dengan serius sebagai akibat dari kemenangan-kemenangan bangsa barat dengan kekuatan lokal di Nusantara. Bermodal kemenangan-kemenangan itu bangsa bangsa kemudian menentukan batas wilayah laut tanpa mempertimbangkan kepentingan-kepentingan masyarakat lokal baik di bidang ekonomi maupun politik ( 0 . W. Wolter, 1982).

Pada tahun 1616, kongsi dagang Belanda yang lebih dikenal dengan VOC mengirimkan 
utusannya ke Makassar. VOC mengirim utusan itu dengan agenda yakni melarang orang Massakar untuk melakukan kegiatan perdagangan di Kepulauan Maluku. Larangan VOC tersebut jelas jelas merugikan orang Makassar terutama bidang perdagangan dan pelayaran (Tommy H. Purwaka, 1993). Tahun 1939, pemerintah kolonial hindia belanda membuat sebuah undang-undang yang berkenaan dengan hukum laut secara lebih komprehensif. Pemerintah Hindia belanda mengenluarkan kebijakan ini ialah untuk melindungi hindia belanda, maka pemerintah colonial membuat sebuah ordonansi tentang laut territorial dan lingkungan maritim. Undang-Undang tersebut tertuang dalam Staatblad tahun 1939 No 442 tentang 'Territoriale Zee En Maritieme Kringen Ordonantie'. Ordonansi tersebut tertuang dalam artikel 1 ayat 1 yang berbunyi bahwa laut teritorial Hindia belanda adalah tiga mil laut dari garis air surut pulau-pulau atau bagian bagian pulau yang termasuk wilayah hindia belanda. diluar jarak sejauh tiga mil tersebut ialah laut bebas dan laut internasional, yang berarti semua kapal asing dapat dengan leluasa mengarungi lautan Nusantara. Dapat di pastikan prinsip laut bebas dan konsep "pulau demi pulau" yang dilakukan Pemerintah Kolonial Hindia Belanda ialah untuk memudahkan pengepungan terhadap hindia belanda itu sendiri.

Saat merdeka pun bangsa Indonesia belum mampu untuk membuat peraturan sen diri, bangsa Indonesia masih menggunakan produk buatan Belanda. Hal ini karena Indonesia masih sibuk mengurusi urusan dalam negeri yang banyak terjadi pemberontakan. Usaha untuk mengubah hukum laut tersebut dimulai dari kabinet Ali II, tetapi kabinet Ali II sudah bubar. Usaha ini di lanjutkan dengan Kabinet Djuanda, yakni dengan menunjuk Mr. Mocthar Kusumaatmaja untuk mencari dasar hukum laut yang tepat bagi Indonesia. akhirnya Mr. Mocthar mengusulkan Konsep Archipilagic Principle, atau Prinsip Kepulauan yakni sebuah sebuah prinsip yang menyatukan semua unsur wilayah negara, baik lautan dan daratan. Dalam sidang dewan menteri tanggal 13 Desember 1957, usulan Mr. Mochtar Kusumaatmajaya di terima dan dijadikan sebgai landasan hukum laut Indonesia. Selanjutnya usulan tersebut di jadikan sebuah deklarasi oleh Dewan Menteri. Deklarasi tersebut lebih dikenal dengan Deklarasi Djuanda.

Deklarasi ini dibawah kedalam forum internasional, yakni United Nations Conference Law of the Sea (UNCLOS). dalam forum tersebut Indonesia berkesempatan untuk menyampaikan gagasannya. Gagasan mengenai negara kepulauan tersebut, banyak mendapat tentangan dari negara luar, dan negara-negara besar. Hal ini karena konsep tersebut baru dalam tata hukum laut internasional. Walaupun mendapat penolakan, tetapi Indonesia tetap berusaha dengan gigih memperjuangkan usulannya, salah satunya ialah dengan menterjemahkan Deklarasi Djuanda ke dalam hahasa Inggris. Dengan harapan banyak bangsa dan negara yang bersimpati dengan usulan dan perjuangan Indonesia.

Sejak di umumkan tanggal 13 Desember 1957, Deklarasi Djuanda mendapat mendapat protes dari negara-negara kepulauan besar di dunia. Protes yang dilakukan antara lain melalui tulisan di surat kabar, melalui radio, dan melakukan protes secara diplomatik kementerian luar negeri Indonesia. Protes secara diplomatik tersebut me ngalir dari negara-negara besar mulai tanggal 30 Desember 1957. Dimulai dari Amerika Serikat yang melayangkan protes tanggal 30 Desember 1957, disusul Inggris tanggal 3 Januari 1958, Australia 3 Januari 1958, Belanda 3 Januari 1958, Perancis 3 Januari 1958, dan Selandia Baru 1958 (Surat Kabar Harian Umum, 1958). Tidak hanya negara yang melakukan protes, beberapa organisasi dunia yang mempunyai kepentingan di perairan Indonesia juga turut melakukan protes. Protes tersebut misalnya datang dari SEATO, suatu organisasi pertahanan negara-negara barat.

Bahkan dalam penyataan terpisah, SEATO mengatakan bahwa kehendak SEATO yang ingin melakukan latihan perang di perairan kepulauan Indonesia , SEATO berpendapat, bahwa sesudah jarak tiga mil, maka perairan 
yang ada di kepulauan Indonesia bukan lagi menjadi wilayah dari Negara Kesatuan republik Indonesia. atas penolakan tersebut, Indonesia akhirnya menyimpulkan bahwa wilayah negaranya memang sangat strategis bagi negara-negara barat dan sangat menguntungkan, baik itu secara ekonomi maupun secara militer. Oleh karena itulah Indonesia berpikir untuk segera menaikkan status Deklrasi Djuanda yang tadinya hanya sebuah pengumuman pemerintah menjadi sebuah produk hukum yang sifatnya formal dan legal.

\section{Tingkat Keberhasilan dan Dampak Kebi- jakan Politik Luar Negeri}

Berhasil tidaknya sebuah kebijakan yang dijalankan pada suatu pemerintah dapat lihat dari aspek timbal balik dari apa yang dijalankan. Selain itu, berhasil tidaknya sebuah kebijakan dapat juga di ukur dengan respon atau tanggapan dari negara lain atas apa yang diwacanakan atau apa yang diterapkan. Kabinet Djuanda dengan programya pancakarya tersebut, telah menterjemakanya menjadi beberapa kebijakan. Salah satu kebijakan tersebut ialah kebijakan politik politik luar negeri.

Kebijakan politik luar negeri kabinet Djuanda ini, sering kita kenal dengan Deklrasi Djuanda. Deklarasi Djuanda dalam isinya menjelaskan tentang bagaimana penerapan sistem asas kepulauan dalam sebuah negara. Deklarasi tersebut juga menjelaskan apa itu Prinsip kepulauan kepada negara lain di dunia. Kebijakan ini terbilang berhasil karena pemerintah melalui kabinet Djuanda telah berani merubah Undang-Undang tentang wilayah laut Indonesia buatan kolonial belanda. Keberhasilan ini juga ditunjukkan dengan keberanian Indonesia menyampaikan asas kepulauan ini kepada dunia internasional.

Dalam konvensi hukum laut tahun 1958 di jenewa, Indonesia berhasil memasukkan usulannya untuk landas kontingen negara, tetapi Indonesia gagal dalam diplomasi guna memuluskan usulannya tentang negara kepulauan. Pencapaian terbesar ialah dengan kabinet Djuanda ialah dengan megikuti Konvensi Hukum Laut yang Pertama, dan berhasi menegaskan ke dunia internasional bahwa Luas Wilayah laut Indonesia ialah $12 \mathrm{Mil}$ di tarik lurus dari garis pangkal pulau. Tetapi kabinet ini juga mengalami kegagalan yang besar karena tidak berhasil membawa konsep negara kepulauan di terima oleh dunia dalam konvensi hukum laut.

Keberanian kabinet ini untuk mengubah sistem hukum laut internasional tidak dapat dipandang remeh lagi oleh negara lain. Deklarasi Djuanda tanggal 13 Desember 1957, sebagai bentuk Kebijakan politik Luar negeri Indonesia mengalami kegagalan. Kegagalan ini karena dalam Konvensi Hukum laut I usulan konsep negara kepulauan yang di ajukan oleh Indonesia ditolak dan banyak mendapat protes dari negara maritim besar dunia. Penolakan negara lain lebih kepada lebar laut yang 12 mil namun menerima usul untuk sistem penarikan garis-garis pangkal lurus. Konferensi ini berakhir dengan menghasilkan keputusan empat perjanjian internasional, tanpa membahas masalah lebar laut wilayah negara. serta Indonesia menarik kembali usulannya karena belum mendapat cukup pengertian dan dan dukungan dari negara lainnya.

Selain berhasil kebijakan ini juga membawa dampak bagi kehidpan negara Indonesia , dampak tersebut terlihat dari berbagai aspek, yakni aspek wilayah, aspek politik dan aspek ekonomi. secara wilayah Setelah Deklarasi Djuanda 13 desember 1957, Indonesia memberlakukan asas negara kepulauan bagi seluruh wilayahnya. dan jarak 3 Mil tidak lagi berlaku, tetapi menjadi 12 Mil laut. Sehingga dengan 12 mil laut tersebut, maka tidak ada lagi istilah laut bebas di antara wilayah Indonesia. Maka utuh dan bulatlah sudah wilayah negara Indonesia. Deklarasi Djuanda tersebut mengakibatkan luas wilayah Republik Indonesia bertambah 2,5 kali lipat dari $2.027 .087 \mathrm{~km}^{2}$ menjadi $5.193 .250 \mathrm{~km}^{2}$ dengan pengecualian Irian Jaya yang walaupun wilayah Indonesia tapi waktu itu belum diakui secara internasional karena masih bersengketa dengan Belanda. Berdasarkan perhitungan 196 garis batas lurus (straight baselines) dari titik pulau terluar (kecuali Irian Jaya), terciptalah garis 
maya batas mengelilingi RI sepanjang 8.069,8 mil laut (http://www. bakorsurtanal. go. id).

Selain berdampak pada aspek kewilayahan, kebijakan ini berdampak pula pada aspek politik. Keluarnya Deklarasi Djuanda yang menjadikan wilayah Indonesia menjadi satu kesatuan yang utuh maka, peta politik juga ikut berubah. Politik Indonesia tidak lagi pada pulau, tetapi lebih kepada konsep Politiknasional.Indonesiamerupakan satu kawasan kepualauan terbesar dunia, maka konsep politik yang hendaknya dipakai ialah konsep politik kawasan, atau Geopolitik. Geopolitik berasal dari kata geo=bumi, politik = Kekuasaan. Secara harfiah berarti politik yang dipengaruhi oleh kondisi dan konstelasi geografi. Maksudnya adalah pertimbangan-pertimbangan dasar dalam menentukan alternatif kebijaksanaan nasional untuk mencapai tujuan nasional, dipengaruhi geografi. Geopolitik Indonesia ialah suatu pemahaman tentang negara Indonesia yang menganut paham negara kepuluan, yaitu paham yang dikembangkan dari asas archipelago yang memang berbeda dengan pemahaman archipelago dinegara-negara barat pada umumnya. Menurut paham barat, laut berperan sebagai "pemisah" pulau. Sedangkan menurut paham Indonesia laut adalah "penghubung" sehingga wilayah negara menjadi satu kesatuan yang utuh sebagai "tanah Air" dan disebut "negara kepulauan". Maka, Geopolitik ialah konsep politik yang memandang suatu kawasan atau wilayah Geografis yang berada dalam suatu wilayah hukum yang menyatu. geopolitik hendaknya dipakai sebagai acuan dasar bagi pemerintah dalam membuat kebijakan politik nasional (http:// wartawarga. gunadarma. ac. id/2010). Aspek ekonomi juga membawa dan berpengaruh terhadap Indonesia, dengan bertambahnya wilayah Indonesia maka ekonomi Indonesia juga akan kuat dan maju karena wilayah laut Indonesia kaya akan sumber daya alam yang dapat membuat perekonomian Indonesia maju pesat.

Pasca demisionernya kabinet Djuanda, maka pemerintah menaikkan status Dekla rasi Djuanda menjadi Undang-Undang yakni
Peraturan Pemerintah Pengganti UndangUndang no 4 tahun 1960 tentang perairan Indonesia. dinaikkannya Deklarasi Djuanda ini adalah karena kegagalan Indonesia dalam UNCLOS I dan II di Jenewa.

\section{Berakhirnya Kabinet Djuanda}

Konstituante hasil pemilu 1955 mulai bekerja pada akhir 1956, tepatnya setelah Presiden Soekarno melantik anggota Konstituante pada tanggal 10 November 1956. Saat bersidang ada 42 hal yang patut dimasukkan dalam Undang Undang Dasar yang baru. Sementara itu 7 hal lain masih di perdebatkan dalam konstituante, yakni masalah Fede ralisme atau Unitaris, bentuk pemerintahan Parlementer atau Presidensiil, masalah dasar negara, masalah wakil kepala negara, serta yang paling prinsip ialah masalah ideologi Negara (Zulfikar Gazali, dkk, 1989). Kons tiante Bersidang selama 2 tahun, dan selama dua tahun tersebut Konstiuante tidak menghasilkan apa-apa. Akhirnya muncul wacana untuk kembali ke UUD 45 sebagai dasar negara. Akhirnya pada tanggal tanggal 30 Mei 1959, Konstituante akhirnya sepakat untuk mengadakan sidang guna menetapkan Undang-Undang Dasar 1945 sebagai dasar negara Republik Indonesia.

Pada tanggal 30 Mei tersebut sidang memilih cara pemungutan suara untuk menentukan Undang-Undang Dasar 1945 sebagai dasar negara. Pada pemungutan suara pertama tanggal 30 Mei hadir peserta sebanyak 468 orang, 269 diantaranya setuju dengan Undang-Undang Dasar 1945 dan 199 orang menyatakan tidak setuju. Hasil pemungutan suara ini menunjukkan mayoritas ingin kembali ke Undang-Undang Dasar 1945. Sayangnya, menurut tata tertib sidang, hasil tersebut belum quorum atau 2/3 dari jumlah keseluruhan, berarti minimal 316 suara.

Pengumutan suara dilakukan kembali pada tanggal 1 Juni 1959. Pemungutan suara yang kedua ini dihadiri oleh 466 peserta, hasilnya 263 setuju dan 203 menyatakan tidak setuju. Pemungutan suara yang kedua ini tetap tidak mencapai quorum, Pemungutan suara dilanjutkan lagi tanggal 2 Juni 1959. Pemungutan suara tanggal 2 Juni ini, merupakan pemungutan suara yang 
ketiga sekaligus yang terakhir dalam sidang Konstituante. Dalam pemungutan suara ini, banyak peserta yang hadir 468 peserta dengan hasil 264 peserta menyatakan setuju dan 204 menyatakan tidak setuju. Sidang Konstituante sebanyak tiga kali berturutturut mulai dari tanggal 30 Mei sampai 2 Juni 1959 tetap tidak menghasilkan keputusan apapun.

Pada masa ini Konstituante memasuki masa Floating Mass atau massa mengambang, yakni suatu masa dimna terjadi titik jenuh, yakni banyak anggota Konstituante yang sudah malas untuk menghadiri sidang, dan juga banyak yang memboikot konsituante. Sedangkan masyarakat terus berharap akan lahirnya sebuah undang-undang Dasar baru yang memang benar-benar mengakomodir semua keinginan dan tuntutan. Kenyataan ini menghadapkan Presiden Soe karno untuk memilih mengeluarkan sebuah kebijakan. Kebijakan tersebut yakni mengeluarkan Dekrit Presiden. Saat masih berada di luar negeri, Presiden menerima kawat dari Soewiryo yang berisi agar presiden segera mengeluarkan Dekrit kembali kepada Undang-Undang Dasar 1945. Pada saat itu Soewiryo ialah kader PNI yang menjabat sebagai ketua umum PNI. Setelah pulang dari kunjungannya ke luar negeri, presiden Soekarno memanggil pejabat penting untuk berdiskusi mengenai Dekrit Presiden dan permasalahan negara. Setelah sekian lama berdiskusi, akhirnya presiden Soekarno mengatakan akan mengeluarkan Dekrit. Tertanggal 3 Juli 1959 Presiden dengan resmi mengatakan kepada kabinet bahwa ia akan mengeluarkan Dekrit. Dekrit ini disusun oleh Presiden, PM. Djuanda, Moh. Yamin, A. H. Nasution, dan Mr. Wahab. Perlu di ketahui bahwa TNI AD adalah salah satu yang menyetujui Dekrit Presiden (Bibit Suprapto, 1985).

Tanggal 5 Juli 1959, Presiden Soekarno mengeluarkan Dekritnya, adapun isi dekrit tersebut secara ringkas ialah (a) Pembubaran Konstituante,(b) Tidak berlakunya UUD Sementara 1950, (c) Berlakunya kembali UUD 1945, (d) Pembentukan MPRS dan DPAS dalam jangkah waktu yang singkat. Dengan dibacakannya Dekrit Presiden maka dengan resmi berlakunya kembali UUD 45 sebagai Dasar Negara. sehingga secara otomatis kabinet Djuanda Demisioner. Hal ini Karena kabinet Djuanda dibentuk dengan UUD Sementara 1950. Dengan berlakunya Sistem Pemerintahan dan Demokrasi yang baru di Indonesia yakni demokrasi terpimpinnya Soekarno, maka bubarlah pula kabinet Djuanda atau Kabinet Karya yang juga menandai berakhirya sistem demokrasi parlementer di Indonesia.

\section{SIMPULAN}

Kebijkan politik luar negeri, berhasil memperkenalkan konsep negara kepulauan kepada konferensi Hukum Laut. Tetapi konsep negara kepulauan yang usung oleh delegasi Indonesia gagal di terima saat konferensi. kegagalan tersebut, ialah ketidak berhasilan kabinet ini. Kabinet ini dalam memperjuangkan masalah kemaritiman hanya dari tahun 1957-1959. Itu artinya hanya pada saat konferensi hukum laut yang pertama. Pada konferensi hukum laut yang pertama ini Indonesia gagal menempatkan usualannya yakni 12 mil lebar wilayah territorial suatu negera kepulauan.

Deklarasi Djuanda pada tanggal 13 Desember 1957 membawa dampak bagi kehidupan Indonesia , baik dari aspek kewila yahan, dari aspek ekonomi, dari aspek politik, dan dari aspek pertahanan keamanan dan aspek sosial budaya. Dari sisi ekonomi, Jelas deklarasi Djuanda menguntung bagi Indonesia, karena Indonesia dapat mengeksploitasi sumberdaya alam yang ada di daratan, maupun diwilayah lautan seperti di daerah lepas pantai. Dari sisi pertahanan keamanan Indonesia mempunyai tugas yang berat untuk menjaga keutuhan wilayah Indonesia dari sektor maritim. Fungsi Pertahanan keamanan ini kemudian diserahkan kepada TNI AL selaku penguasa dan ujung tombak pertahanan keamanan wilayah Republik Indonesia.

Perjuangan dilanjutkan ketika masa kabinet kerja, pasa tahun 1960 pemerintah memperkuat posisi deklrasi Djuanda menjadi sebuah Undang-Undang. Yakni UU No. 4/ PRP 
1960 tentang perairan Indonesia. Kabinet Djuanda demisioner bukan karena mendapat mosi tidak percaya dari parlement. Kabinet ini demisioner karena perubahan struktur politik negara Indonesia. Kabinet ini demi sioner karena gagalnya konstituante menyusun Undang-Undang Dasar baru serta keluarnya Dekrit Presiden tanggal 5 Juli 1959. Dekrit ini mengubah struktur politik dari parlementer ke presiden sill, serta dari Libe ral kedemokrasi terpimpin. Setelah Dekrit keluar pada tanggal 5 Juli, tanggal 6 Juli 1959 Perdana Menteri Djuanda menyerahkan kembali mandat yang diterima. Tetapi kabinet ini tetap bekerja hingga kabinet baru dibentuk oleh presiden. Kabinet ini bekerja sebagi kabinet demisioner.

\section{UCAPAN TERIMA KASIH}

Diucapkan terima kasih kepada semua pihak yang telah membantu proses penelitian ini. Kami juga turut mengucapkan terima kasih kepada Dewan Redaksi atas termuatnya artikel ini dalam jurnal sehingga artikel ini dapat dibaca oleh berbagai kalangan.

\section{DAFTAR PUSTAKA}

Dewan Kelautan Indonesia. 2009. Himpunan Peraturan Perundangan-Undangan di Bidang Kelautan, Jakarta: Sekretariat Dewan Kelautan Indonesia.
Duta Masyarakat, SOB Di Umumkan di seluruh Indonesia, Tanggal 15 Maret, 1957.

Gazali, Zulfikar, dkk. 1989. Sejarah Politik Indonesia. Jakarta: Departement Pendidikan dan Kebudayaan Direktorat Sejarah dan Nilai Tradisional Proyek Inventarisasi dan Dokumentasi Sejarah Nasional.

Hamzah, A. 1984. Laut, Territorial dan Perairan Indonesia: Himpunan Ordonansi, Undang-Undang dan Peraturan Lainnya, Jakarta: Akademika Pressindo.

Kementrian Penerangan RI. 1970. Susunan dan Program Kabinet Selama 25 Tahun. Jakarta : Pradjna Paramitha.

Mirnawati. 2012. Kumpulan Pahlawan Nasional, Jakarta: Penerbit Swadaya Group

Nanulaita, I. O. 1983. Ir. H. Djuanda Kartawijaya. Jakarta:Departement Pendidikan dan Kebudayaan, Direktorat Sejarah dan Nilai Tradisional Proyek Inventarisasi dan Dokumentasi Sejarah Nasional.

Purwaka, Tommy H. 1993. Pelayaran Antar- Pulau Indonesia, Jakarta: Pusat Studi Wawasan Nusantara, Hukum, dan Pembangunan, Bumi Aksara.

Siahaan, N. H. T, dkk. 1989. Hukum Laut Nasional: Himpunan Peraturan Perundangan-Undangan Kemaritiman. 